\title{
3.2 Methodological foundations of ecological education of preschool children
}

Екологічна освіта поза всяким сумнівом є одним із найважливіших напрямів сучасної педагогічної науки. Ї̈і актуальність обумовлена необхідністю виховати наступні покоління на нових світоглядних засадах, завдяки чому лише й можливе подолання екологічних проблем людства. Крім того, екологічна освіта розглядається сучасними науковцями та практиками як провідний чинник гуманізації освітнього процесу, важливий фактор особистісного розвитку дитини.

У сучасній філософській та психолого-педагогічній науці немає дискусії про те, коли саме слід розпочинати екологічну освіту. Сензитивним періодом для формування основ екологічної культури є дошкільний вік, коли дитина починає пізнавати навколишній світ. Саме тоді закладається система цінностей, якими вона керуватиметься у своїй взаємодії з цим світом. На дошкільний вік припадає надзвичайно важливий етап становлення екологічної культури, пов'язаний із формуванням у дитини первісних уявлень про природу, виробленням емоційнопозитивного ставлення до неї, усвідомленням себе як частини природи, яка існує у нерозривній єдності з іншими компонентами довкілля. На цій основі у дитини виникає відчуття відповідальності за те, що відбувається навколо неї та внаслідок їі дій у довкіллі.

Результативність екологічної освіти дошкільнят значною мірою залежить від особистої позиції дорослих, які їх виховують, їх екологічного світосприймання та вміння передати малюкам своє ставлення до природи, розуміння власної ролі у іiі збереженні. Хоча, безперечно, роль батьків у формуванні ціннісних орієнтацій та базису особистісної культури дитини величезна, але в цьому випадку ми маємо на увазі в першу чергу педагогів, вихователів закладу дошкільної освіти, де уже 3 перших років життя малюка здійснюється систематичне, цілеспрямоване ознайомлення дітей із світом природи. Актуальність екологічної освіти підростаючого покоління привела до 
надання усій роботі по ознайомленню дошкільників з природним довкіллям екологічного спрямування.

У зв’язку з цим особливе місце серед загальних питань дошкільної педагогіки та методики ознайомлення дітей з природою займає проблема вибору методологічних засад, на яких, у свою чергу, грунтується визначення конкретних завдань та принципів, що стануть найголовнішими у роботі 3 дітьми. Від цього залежатиме уже й розробка власне методики екологічної освіти: визначення змісту природознавчих уявлень, які складуть основу екологічного світосприйняття, обгрунтування методів, методичних прийомів та форм пізнання дітьми дошкільного віку світу природи.

Для визначення методологічних основ екологічної освіти проаналізуємо філософські та філософсько-педагогічні концепції, у яких розглядаються питання про місце людини у довкіллі, взаємозв'язок людини, природи та суспільства. Серед них найбільший вплив на розвиток сучасної освіти, у тому числі, й дошкільної, має концепція сталого розвитку. Як зазначають О. Ватченко та В. Ільченко [234], усвідомлення того, що основою формування майбутнього людства є сталий (збалансований, стійкий) розвиток, яке почало з’являтися у останній чверті XX сторіччя, стало новим етапом у розвитку суспільства i сформувало нову парадигму наукового мислення. Автори наводять визначення поняття «сталий розвиток», зафіксоване у документах Міжнародної комісії 3 навколишнього середовища і розвитку (1987р.): «Це такий розвиток, який задовольняє потреби сьогодення, але не ставить під загрозу можливість майбутніх поколінь задовольняти свої потреби» [234, с. 65].

Отже, «Сталий розвиток» (англ. «Sustainable development») - це загальна концепція стосовно необхідності встановлення балансу між задоволенням сучасних потреб людства і захистом інтересів майбутніх поколінь, включаючи їх потребу в безпечному i здоровому довкіллі [234, с. 65]. Саме на цій методологічній основі можливе формування екологічної культури і дорослих, i дітей, починаючи з дошкільного віку. 
Інтерес педагогіки до цієї філософсько-екологічної концепції не випадковий, адже з іï аналізу серед іншого випливає, що екологічна освіта має розвиватися випереджальними темпами, оскільки, вона може стати основою нової моделі освітньої системи як необхідного елемента переходу сучасної цивілізації до сталого розвитку [235, с. 46]. Саме з огляду на це, у Базовому компоненті дошкільної освіти [236] визначено основну мету ознайомлення дітей 3 природою як формування у них природничо-екологічної компетенції та навичок, орієнтованих на сталий розвиток. Зрозуміло, що ці два важливих завдання між собою тісно взаємопов'язані. Природничо-екологічна компетенція - це здатність дитини до доцільної поведінки в різних життєвих ситуаціях, що грунтується на емоційно-ціннісному ставленні до природи, знаннях іiі законів та формується у просторі пізнавальної, дослідницької, трудової, ігрової діяльності. Навички, орієнтовані на сталий розвиток, виявляються у сформованості в дітей початкових уявлень про сталі дії і поведінку, усвідомленні необхідності збереження ресурсів планети й особистої причетності до цього; розвиненості ефективних звичок соціальної поведінки, економного споживання ресурсів та збереження природи [236].

О. Каверін та Д. Массеров наголошують, що освіта для сталого розвитку має складний міждисциплінарний характер, який вимагає поєднання традиційних освітніх методів з активними методами освіти, такими як імітаційні ігри, ігрові методи створення команд, робота в малих групах, ділові ігри [235, с. 50] тощо. Зразком такого підходу є науково-методичні розробки українських вчених Н. Гавриш та О. Пометун «Дошкільнятам - освіту для сталого розвитку» [237]. Програма спрямована на формування у дітей, а через них - і у їхніх батьків та самих педагогів, які іï реалізовують у закладах дошкільної освіти, життєво важливих навичок екологічно-, економічно- й соціально доцільної поведінки, без якої неможливе створення та існування суспільства, орієнтованого на сталий розвиток. Перелік запропонованих авторами програми тем охоплює взаємодоповнюючі сфери сталого розвитку: соціальну, економічну та екологічну й є традиційним для освіти для сталого розвитку [237]. 
3 філософської точки зору в основі концепції сталого розвитку за великими рахунком лежить біоцентризм, який є одним з відгалужень екоцентризму - течії біоетики, що виходить 3 уявлень про явний пріоритет збереження екологічної сфери планети (включаючи і їі неживі елементи) над задоволенням поточних потреб людини, і розглядає як самостійну цінність екосферу в цілому. На жаль, у нашому суспільстві ще й досі не зжиті погляди, в основі яких лежить протилежне до біоцентризму філософське спрямування - антропоцентризм, при якому в системі люди - природа людина розглядає себе як головну дійову особу, яка може змінити своє оточення як їй заманеться, для власного блага і спрямовує свою діяльність на підкорення природи. Історико-педагогічний аналіз доводить, що впродовж майже всього періоду становлення i розвитку методика ознайомлення 3 природою дітей дошкільного віку, як і методика вивчення природознавства у школі, будувалися переважно на антропоцентричній методології. Тому при доборі конкретного змісту освітньої роботи 3 дошкільниками, розробці методів та технологій важливо уникнути ситуації, коли мета і завдання екологічної освіти базуються на новій екологічній парадигмі (біоцентризмі, концепції сталого розвитку), а добір змісту і методик мимоволі повертає до старої парадигми - антропоцентричної. До прикладу, відлунням антропоцентричного підходу у змісті уявлень дошкільників про природу $є$ традиція поділу рослин і тварин на корисних і шкідливих, красивих і потворних і навіть подекуди «хороших» і «поганих». Хоча у більшості випадків вихователі уникають таких прямих означень, але часто підштовхують дітей до подібних висновків непрямо. Скажімо, такі, здавалося б «правильні» теми, як лікарські рослини, їстівні та отруйні гриби, свійські тварини, за неправильно розставлених акцентів можуть вести до формування споживацького погляду на навколишній світ, виробляти у дітей уявлення про необхідність дбайливо ставитися тільки до тих об'єктів природи, що мають практичне значення для людини, i про необов'язковість такого ставлення до інших, що суперечить ідеї самоцінності природи, яка лежить в основі біоцентризму. 
Пошук методологічних засад екологічної освіти дітей дошкільного віку примушує звернути увагу також на філософське вчення про соціальноекологічний ідеал - образ досконалого навколишнього світу, який виникає у свідомості людини чи всього людства в результаті опанування знаннями про навколишній світ та набуття досвіду його перетворення. У реальній практиці функціонування сучасного суспільства соціально-екологічний ідеал трансформується через систему освіти у своєрідний ідеал стійкого розвитку людини і біосфери [238]. В його основі лежать ті ж самі філософські концепції стійкого розвитку та біоцентризму, які умовно можна об'єднати у так звану філософію виживання людства загалом та його окремих складників зокрема.

Оскільки формування соціально-екологічного ідеалу відбувається саме у процесі пізнання дитиною навколишнього світу, важливо не лише зрозуміти сутність ідеалу та його складові. У освітній роботі слід врахувати, які $з$ цих складників формуються уже в дошкільному віці, і обрати ефективні засоби впливу на дитину. Аналізуючи проблему соціально-екологічного ідеалу, дослідники А. Гайдамак та Т. Тійтанен [238] зазначають, що його формування базується на певній сукупності знань, зокрема, основ екології, які дитина починає опановувати 3 дошкільного віку. Численними дослідженнями i практикою дошкільної освіти доведено, що дошкільнятам доступні чимало екологічних понять (знання про залежність живих організмів від умов існування: екологічні потреби рослин, пристосувальні властивості тварин, сезонні зміни в живій та неживій природі тощо), тому їх засвоєння передбачається більшістю програм розвитку і виховання дітей дошкільного віку. Однак для повноцінного ідеалу самих знань недостатньо, тому екологічна освіта дошкільників - це не тільки сума знань, але й оцінка, усвідомлення екологічної цінності природи в іiі єдності з людиною. Послідовність формування соціально-екологічного ідеалу особистості та його зміст з точки зору біоцентричної філософської концепції можна подати у вигляді наступної схеми (таблиця 1). 
Таблиця 1

Послідовність формування соціально-екологічного ідеалу

\begin{tabular}{|c|c|c|}
\hline $\begin{array}{c}\text { Складові частини } \\
\text { соціально - } \\
\text { екологічного ідеалу }\end{array}$ & $\begin{array}{c}\text { Зміст з точки зору } \\
\text { біоцентричної парадигми }\end{array}$ & $\begin{array}{l}\text { Віковий період, } \\
\text { сензитивний для } \\
\text { формування }\end{array}$ \\
\hline $\begin{array}{c}\text { Ідеал світу красивого } \\
\text { (Естетичний } \\
\text { компонент) }\end{array}$ & $\begin{array}{c}\text { Емоційно-позитивне ставлення } \\
\text { до природи; естетичне } \\
\text { сприймання природи. }\end{array}$ & $\begin{array}{c}\text { Ранній та молодший } \\
\text { дошкільний вік. }\end{array}$ \\
\hline $\begin{array}{c}\text { Ідеал світу доброго } \\
\text { (Моральний } \\
\text { компонент) }\end{array}$ & $\begin{array}{c}\text { Усвідомлення самоцінності } \\
\text { природи; уявлення про } \\
\text { моральне ставлення людини до } \\
\text { природи. }\end{array}$ & $\begin{array}{l}\text { Середній та старший } \\
\text { дошкільний вік. }\end{array}$ \\
\hline $\begin{array}{l}\text { Ідеал світу } \\
\text { розумного } \\
\text { (Когнітивний } \\
\text { компонент) }\end{array}$ & $\begin{array}{c}\text { Знання основ екології - науки } \\
\text { про взаємозв'язки у природі. }\end{array}$ & $\begin{array}{c}\text { Старший дошкільний та } \\
\text { шкільний вік. }\end{array}$ \\
\hline $\begin{array}{c}\text { Ідеал світу } \\
\text { активного } \\
\text { (Дієвий компонент) }\end{array}$ & $\begin{array}{c}\text { Спілкування з природою; } \\
\text { перетворення природи } 3 \\
\text { врахуванням її законів; охорона } \\
\text { природи. }\end{array}$ & $\begin{array}{c}\text { Старший дошкільний та } \\
\text { шкільний вік. }\end{array}$ \\
\hline
\end{tabular}

Як бачимо з таблиці, для трьох-чотирьохрічних малюків ідеальний світ це світ красивий, яскравий, сприймання якого дарує естетичну насолоду. У чотири-п'ять років починається усвідомлення цінності природи, яке виростає на основі емоційно-позитивного ставлення до природи, пов'язаного з ії естетичним сприйняттям. Досить часто діти цього віку пояснюють своє ставлення до того чи іншого об'єкта природи саме красою (те, що було сприйняте, як прекрасне, вже тільки через це є цінним). У зв'язку з цим, як наголошують А. Гайдамак та Т. Тійтанен [238], у дошкільний період у процесі формування екологічного ідеалу основна увага має приділятися саме естетичній і моральній його сторонам, конкретніше, вихованню морально- і естетико-екологічних знань. Важливою особливістю формування естетичного та морального компонентів екологічного ідеалу є їх нерозривна єдність, де моральне (а виходить, і прекрасне) ставлення до природи розглядається як моральне (і тому прекрасне) стосовно інших людей, тому що природа $є$ тим середовищем, без якого немислиме людство [238]. 
Не можна не погодитися 3 думкою А. Гайдамак та Т. Тійтанен [238], що основним засобом формування соціально-екологічного ідеалу в дошкільному віці може стати казка. Вчені справедливо зазначають, що історично казка виступає як певний рівень вираження знань і вимислу, ціннісних орієнтації $\mathrm{i}$ сподівань, кращої поведінки людини, тобто як певний рівень вираження ідеалу людства. Саме в казці в дивному сплаві поєднуються у ставленні до природи добре і прекрасне, зле і потворне, що знаходить висвітлення не тільки в змісті, але й в емоційно-образній формі, у мові. Тому пізнавальні, естетичні і моральноповедінкові завдання формування соціально-екологічного ідеалу вирішуються через казку в їхній єдності.

Казки про тварин, які традиційно використовують у роботі з дітьми раннього та молодшого дошкільного віку, виступають для малюків своєрідним джерелом першої екологічної інформації: саме 3 казок діти дізнаються про зовнішній вигляд, умови життя та деякі повадки багатьох тварин, в казках відображаються також окремі аспекти ставлення людей до природи, екологічні взаємозв'язки у довкіллі. Сюжети добре відомих дітям народних казок можуть стати основою для проведення заняття у формі гри, метою якої є формування у малят перших узагальнень та природничих понять. Так, українські народні казки «Колобок», «Рукавичка», «Солом'яний бичок» допоможуть сформувати узагальнене поняття про диких тварин та середовище їх існування (ліс), а ознайомлення дітей $з$ домашніми тваринами можна провести, використавши казки «Курочка Ряба», «Котик і Півник» або «Півник і двоє мишенят».

У середній групі, де на перший план повинні вийти моменти активнодієвого та морально-естетичного ставлення до природи, вихователь може використовувати казкових персонажів як приклади такого ставлення. Особливо цінні в цьому плані чарівні казки, у яких яскраво показані позитивне та негативне ставлення до природи. За рахунок уже наявного в казці протиставлення наслідків правильної та неправильної поведінки персонажів дітям легко її оцінити, а також перенести цю оцінку за межі казки, у відповідні ситуації реального життя. Оскільки у цьому віці значно зростає інтерес дітей до художньо-виконавської 
діяльності, 3'являється можливість поєднати казку із провідною діяльністю дошкільнят - грою. Ігри-драматизації, у яких діти відображають у ролях ті чи інші форми екологічної поведінки, даючи при цьому їм оцінку, допомагають дітям набувати досвіду втілення в життя своїх екологічних знань та своїх перших ідеалів.

Розуміння закономірностей формування біоцентричного за змістом соціально-екологічного ідеалу дозволяє проаналізувати з позиції біоцентричної парадигми не лише зміст, а й методи, які найчастіше застосовують вихователі 3 метою екологічної освіти дітей дошкільного віку, Зрозуміло, що казка - не єдиний ефективний засіб формування соціально-екологічного ідеалу в дошкільному віці. Не менш важливим засобом є безпосереднє спілкування дітей 3 природою. Тому особлива увага науковців звернена до тих методів, які можуть забезпечити взаємодію дошкільнят з природним довкіллям. Мова йде у першу чергу про спостереження - метод, що передбачає безпосереднє сприймання дітьми природи. Мета будь-якого спостереження у природі - дати можливість дітям поспілкуватися 3 живим об'єктом, розглянути його, закласти основи для появи у дітей емоційно-позитивного, турботливого ставлення до цього об'єкта. Безперечно, під час спостереження у дітей також потрібно формувати уявлення про рослини та тварин як живі істоти, показувати взаємозв’язки, що існують в природі [239]. Однак, коли мова йде про дітей молодшого дошкільного віку, то у спостереженні головним має бути все ж не пізнавальний, а естетичний аспект. Тобто, перші спостереження, це, швидше, милування природою, адже саме це відповідає потребам дитини сприймати світ з позиції краси. Проводячи спостереження, вихователь повинен пам'ятати, що дитина спочатку помічає в предметі найяскравіше, те, що впадає в око, й емоційно відгукується на нього. Тому під час спостереження слід не лише дати дітям можливість помилуватися явищем природи, а й вільно висловити свої почуття дорослому та один одному. Вже $з$ перших хвилин спостереження дітям необхідно відчути ставлення самого вихователя до спостережуваних явищ природи. У цьому можуть допомогти сюрпризний момент, влучні вислови та описи, яскраві порівняння. Варто 
врахувати, що маленькі діти легко знаходять красу в будь чому (для них красива не тільки троянда, а й колючий будяк; не лише яскравий метелик, а й зелена гусінь чи майже прозорий черв’ячок; як дорога породиста кішка, так і маленьке замурзане дворове цуценя тощо), у них відсутнє сприйняття природного об'єкта як потворного та почуття гидливості до нього, якщо, звичайно, дорослі вже не передали дитині свої негативні установки щодо окремих об'єктів довкілля. А саме цього і слід, в першу чергу уникнути, щоб не повернути уявлення дитини про ідеальний світ у старе антропоцентричне русло.

Отже, проводячи спостереження 3 молодшими дошкільниками, краще використовувати для підвищення пізнавального інтересу дітей прийоми, що впливають на емоційну складову пізнання (загадки, ігрові прийоми, побудовані на персоніфікації об’єктів природи, музика чи художнє слово).

В подальшому, коли діти стають старшими, вихователь має урізноманітнювати методику керівництва спостереженнями, поступово включаючи до іiі структури такі прийоми, які активізують самостійну думку дітей, спонукають до елементарного пошуку, розмірковування [239].

Загалом у екологічній освіті старших дошкільників вже значно більше уваги має надаватися формуванню наступних складових соціально-екологічного ідеалу, когнітивній та дієвій, оскільки саме у цьому віці, який невипадково названо віком чомучок, ідеальний світ дитина уявляє вже не лише як красивий $\mathrm{i}$ добрий, а й як розумний і активний. Дієвими у пізнанні природи стають такі методи, які дозволяють досліджувати світ, перетворювати його (елементарні досліди, творчі ігри та праця у природі, навчальні дослідження, екологічні проєкти тощо).

Підсумовуючи, можемо зробити висновок, що нові світоглядні орієнтири та соціальні завдання, які стоять нині перед людством, вимагають корекції ставлення людини до природи, нових ціннісних орієнтацій та утвердження гуманістичних соціально-моральних позицій щодо використання природи суспільством. Це надає особливої ваги питанню вибору методологічних засад екологічної освіти дітей починаючи 3 дошкільного віку. Найповніше мета 
екологічної освіти може бути досягнута, якщо робота 3 дітьми буде здійснюватися з позицій біоцентричної парадигми, що приведе до формування у підростаючих поколінь екоцентричного соціально-екологічного ідеалу та навичок, орієнтованих на сталий розвиток. 